\title{
Peer Relations in Children with Cochlear Implants
}

\author{
Young Mi Choi ${ }^{1,2}$, Sung Wook Jeong ${ }^{2}$, and Lee-Suk Kim ${ }^{2}$ \\ ${ }^{1}$ Department of Child Development \& Family Studies, Pusan National University, Busan; and ${ }^{2}$ Department of Otolaryngology-Head and \\ Neck Surgery, College of Medicine, Dong-A University, Busan, Korea
}

\section{인공와우이식 아동의 또래관계}

최영미 ${ }^{1,2} \cdot$ 정성욱 $^{2} \cdot$ 김리석 $^{2}$

부산대학교 아동가족학과, ${ }^{1}$ 동아대학교 의과대학 이비인후과학교실 ${ }^{2}$

Received August 7, 2017

Revised November 13, 2017

Accepted November 20, 2017 Address for correspondence

Sung Wook Jeong, MD, PhD

Department of Otolaryngology-

Head and Neck Surgery,

College of Medicine,

Dong-A University,

26 Daesingongwon-ro, Seo-gu,

Busan 49201, Korea

Tel $+82-51-240-5423$

Fax $+82-51-253-0712$

E-mail dau_su@naver.com
Background and Objectives Children who received cochlear implants (CIs) in early age can achieve age-appropriate language ability and can be educated in the classroom alongside normal hearing (NH) peers. However, what is rarely investigated is their relations with $\mathrm{NH}$ peers in the classroom. The purpose of this study was to examine the peer relations of children with CIs.

Subjects and Method Peer relations were examined using a peer relation scale test that included support, intimacy, recognition, conflict, and competition. Participants were 25 children who received their first $\mathrm{CI}$ before 3.5 years of age. Their peer relations were compared with those of 129 children with $\mathrm{NH}$.

Results Children with CIs evaluated themselves as having good peer relations, but their perception of peer relations varied according to gender and language ability. CI boys with language delay perceived lack of support and intimacy, whereas CI girls with language delay perceived more conflict than NH children. On the other hand, CI children with normal language ability showed no differences in their peer relations from $\mathrm{NH}$ children.

Conclusion Early CI surgery and intensive language rehabilitation can prevent peer problems and promote adjustment in school life for children with CI.

Korean J Otorhinolaryngol-Head Neck Surg 2018;61(8):396-402

Key Words Children · Cochlear implant · Peer relations.

\section{서 론}

또래는 특정 연령, 계층, 학력, 지위와 같은 사회적 범주가 동일하거나 유사한 집단에 속하는 사람들을 말하고, 이런 사 람들이 같은 공동체 내에서 생활하며 공동 규범을 공유하고 서로 영향을 주고받는 관계를 또래관계라고 한다.1) 영유아기 에는 주로 가족과 관계를 맺지만 아이가 성장하여 어린이집 이나 유치원과 같은 사회적 집단에 속하게 되면 아동의 관계 망은 또래 및 교사로 확대된다. 이 시기 또래관계는 아동과

This is an Open Access article distributed under the terms of the Creative Commons Attribution Non-Commercial License (https://creativecommons.org/licenses/by-nc/4.0) which permits unrestricted non-commercial use, distribution, and reproduction in any medium, provided the original work is properly cited.
가족 구성원의 관계, 혹은 아동과 교사의 관계와 대조적으로 상호성과 동등성을 전제로 하여 자발적으로 맺어진 관계이 다. ${ }^{2}$ 아동기 또래의 기능은 크게 세 가지로 생각할 수 있다. 첫째, 또래는 놀이, 운동, 교과학습 등 다양한 상황에서 사회 적 규범을 체득하도록 상호 역할모델이 되어 주고, ${ }^{3)}$ 둘째, 또 래와 어울리는 과정을 통해 협력과 협상, 조망수용과 자기조 절능력 등 사회적 기술을 향상시킬 수 있는 기회를 가지게 되 며,5) 셋째, 또래는 사회적 지지원으로서 아동의 정서적 안정 감과 긍정적 자기개념을 형성하도록 돕는 역할을 한다. ${ }^{6}$

아동기와 청소년기를 거치면서 또래관계는 점점 더 안정되 고 친밀해지며 중요해진다. ${ }^{7)}$ 초등 고학년이 되면 신체적 성숙 과 함께 부모로부터 분리되고자 하는 욕구를 가지게 되고 가 
족과 보내는 시간에 비해 또래와 어울리는 시간이 급격히 증 가하게 되면서, 아동은 유사한 가치를 공유하는 또래집단에 소속감을 느끼고 자신의 성격, 가치, 능력 등을 자신이 속한 또래집단을 기준으로 평가하며 또래에게 인정받기 위해 노력 한다. ${ }^{89)}$ 연구에 따르면 친밀하고 지지적인 또래관계를 형성한 아동들은 학교생활이 즐겁다고 느끼고 높은 학업 성취도를 보일 뿐만 아니라 학교 적응력과 사회정서적 능력이 좋은 것 으로 나타났다. ${ }^{10)}$ 반면 또래로부터 수용받지 못하거나 거부 당하는 등 부정적인 또래관계를 형성한 아동들은 공격적 행 동을 보이거나 외로움, 우울감 등의 심리적 문제, 학업부진, 학 교폭력피해 등으로 학교생활에 적응하지 못하거나, ${ }^{11,12)}$ 성장하 면서 부정적인 성격이 형성되어 원만한 대인관계를 맺지 못하 거나 반사회적 문제를 보이는 성인이 될 가능성이 높았다. ${ }^{13)}$

선천성 고도 감각신경성난청 아동을 위한 조기 인공와우이 식 이식이 보편화되면서 이식 후 듣기 수행력과 구어언어능 력이 과거에 비해 크게 향상되었다. 최근의 연구들은 조기에 인공와우이식을 받은 청각장애아동의 말지각력, 수용언어능 력, 표현언어능력, 말명료도, 구어의사소통능력이 정상 청력을 가진 또래와 비슷한 수준으로 향상되었고 이로 인해 많은 인 공와우이식 아동이 일반 학교에서 통합교육을 받고 있다고 보고하고 있다. ${ }^{14-17)}$ 그러나 이러한 우수한 구어의사소통능력 을 바탕으로 또래관계와 같은 심리사회적 영역에서 정상적인 발달을 하고 있는지를 조사한 연구는 매우 부족한 실정이다. 인공와우이식을 포함한 소아 난청재활의 궁극적인 목표가 원 할한 구어의사소통능력을 바탕으로 구어를 사용하는 사회에 성공적으로 통합하는 것이라는 관점에서 인공와우이식 아동 의 심리사회적 발달에 대한 연구가 절실하다고 할 수 있다. 이 에 본 연구에서는 조기 인공와우이식을 받아 양호한 구어의 사소통능력을 획득한 아동을 대상으로 이들이 정상 청력을 가진 또래들과 어떠한 또래관계를 형성하고 있는지 알아보고 자 하였다. 또한 아동기 또래관계 인식에서 성별에 따른 차이 가 있고, ${ }^{18,19)}$ 인공와우이식 아동이 정상 청력을 가진 또래와 의 관계에서 겪는 어려움이 미숙한 언어능력에서 기인한다고 알려져 있어 ${ }^{20)}$ 본 연구에서는 인공와우이식 아동의 성별과 언어능력에 따른 또래관계 인식도 추가로 알아보고자 하였다.

\section{대상 및 방법}

\section{대 상}

본 연구는 인공와우이식을 받은 언어 습득 전 농 아동 중, 중복장애나 심한 내이기형이 없고 3.5 세 이전에 인공와우이식 수술을 받았으며 현재 통합교육 환경에 재학 중인 3 6학년 아동을 대상으로 하였다. 대상자 모집은 연구 대상에 해당되 는 아동과 부모님에게 연구의 목적과 취지를 설명한 후 자발 적인 참여로 이루어졌으며, 총 25 명의 아동이 연구에 참여하 였다. 본 연구에 참여한 인공와우이식 아동 25 명은 모두 서로 다른 초등학교에 재학 중이었고, 자신의 학급에서 본인 외 난 청 아동은 없었다. 정상 청력 대조군은 한 초등학교의 협조 를 얻어 3학년에서 6학년까지 학년당 두 학급의 학생 129 명 으로 하였다(Table 1). 본 연구는 동아대학교병원 임상시험심 의위원회의 승인을 받은 후 진행하였다(DAUHIRB-17-097).

\section{또래관계 척도 검사}

인공와우이식 아동 25 명과 정상 청력 아동 129 명을 대상으 로 또래관계 척도 검사를 시행하였다. 연구에 사용된 검사는 Parker와 Asher")가 개발한 또래관계 척도 검사를 Jung ${ }^{21)}$ 이 수정, 보완, 재구성하여 타당도를 검증한 또래관계 척도 검사 도구이다. 본 척도는 자기보고형 검사로 또래와의 관계를 자 신 스스로가 어떻게 인식하고 있는지를 묻는 검사이다. 도움 (support), 친밀(intimacy), 인정(recognition), 갈등(conflict), 경쟁(competition)의 다섯 가지 하위 영역으로 구성되어 있으 며, 도움 영역 6 문항, 친밀 영역 6 문항, 인정 영역 5 문항, 갈등 영역 9문항, 경쟁 영역 9문항의 총 35문항으로 이루어져 있 다. 도움 영역은 도움이 필요할 때 또래로부터 직접적인 도움 을 받거나 기분이 좋지 않을 때 위로를 받는지에 대한 내용, 친밀 영역은 자신의 고민이나 비밀 혹은 부정적인 감정을 또 래에게 개방하는지 여부에 대한 내용, 인정 영역은 또래로부 터 자아개념을 긍정적으로 형성시켜 줄 수 있는 평가를 받거 나 공감을 받는지에 대한 내용, 갈등 영역은 또래 괴롭힘 혹 은 다툼으로 불편감이 발생하는지 여부를 묻는 내용, 그리고 경쟁 영역은 일상생활에서 또래를 질투하거나 또래보다 더

Table 1. The demographic data of children with $\mathrm{Cls}$ and those with $\mathrm{NH}$

\begin{tabular}{lcc}
\hline & Children with Cls & Children with NH \\
\hline Number of subjects & 25 & 129 \\
boys/girls & $11 / 14$ & $65 / 64$ \\
Chronologic age (years, mean \pm SD) & $10.3 \pm 1.1$ & $10.6 \pm 1.1$ \\
Age at 1st Cl (years, mean \pm SD) & $2.0 \pm 0.8$ & \\
Duration of $\mathrm{Cl}$ use (years, mean \pm SD) & $8.7 \pm 1.2$ & \\
\hline
\end{tabular}

$\mathrm{Cl}$ : cochlear implant, $\mathrm{NH}$ : normal hearing, SD: standard deviation 
잘하기 위해서 노력하는지를 묻는 내용으로 구성되어 있다. 각 각의 문항에 대해서 전혀 그렇지 않다(1점)에서부터 매우 그렇 다(5점)까지 5점 Likert 척도로 응답하도록 되어 있다. 연구에 사용된 또래관계 척도 검사의 5 개 하위 영역 중 도움, 친밀, 인정 영역은 또래관계의 긍정적 요소로서 점수가 높을수록 자신의 또래관계를 좋게 인식하고 있다는 것을 의미한다. 반 면 갈등과 경쟁 영역은 또래관계의 부정적인 요소로서 점수 가 낮을수록 또래관계를 좋게 인식하고 있다는 것을 의미한 다. 본 연구에 참여한 아동에게는 현재의 학급 친구들을 기 준으로 자신의 또래관계를 평가하도록 요청하였다.

\section{분 석}

인공와우이식 아동 전체와 정상 청력 아동 전체의 또래관 계 척도 검사 점수를 비교하였다. 그리고 성별에 따른 차이를 알아보기 위해 인공와우이식 남아와 정상 청력 남아, 인공와 우이식 여아와 정상 청력 여아 간 또래관계 척도 검사 점수 를 비교하였다. 끝으로 언어능력에 따른 또래관계의 차이를 알아보기 위해, 아동들을 언어발달 정상군과 언어발달 지연 군으로 나누어 정상 청력 아동과 또래관계 척도 검사 점수를 비교하였다. 인공와우이식 아동의 언어능력은 국내에서 표준 화 과정을 거쳐 개발되어 있는 Receptive \& Expressive Vocabulary Test(REVT)로 측정하였다. REVT 점수가 -2 standard deviation(SD) 이하인 경우를 언어발달 지연으로, -1 $\mathrm{SD}$ 이상인 경우를 정상 언어발달로 판정하였다.

통계분석은 SPSS(version 23; IBM Corp., Armonk, NY, USA)를 이용하여 독립표본 t-test와 Mann Whitney U-test 를 시행하였다.

\section{결 과}

인공와우이식 아동과 정상 청력 아동의 또래관계 인식 비교 또래관계 척도 검사의 5 가지 하위 영역 중 또래관계의 긍
정적 요소인 친밀, 인정, 도움 영역의 총점은 인공와우이식 아동이 정상 청력 아동에 비해 유의하게 낮았다 $(p=0.033)$. 그러나 하위 영역별로 살펴보면 도움 영역만 인공와우이식 아동이 정상 청력 아동에 비해 유의하게 낮은 점수를 보였고 $(p=0.001)$, 친밀 영역과 인정 영역의 점수는 인공와우이식 아 동과 정상 청력 아동 간 유의한 차이가 없었다 $(p=0.237,0.506)$ (Fig. 1A). 또래관계의 부정적 요소인 갈등, 경쟁 영역의 총점 은 인공와우이식 아동이 정상 청력 아동에 비해 유의하게 높 았다 $(p=0.035)$. 그러나 하위 영역별로 살펴보았을 때 갈등 영 역과 경쟁 영역 각각의 평균 점수는 두 집단 간 유의한 차이 가 없었다 $(p=0.113,0.064)$ (Fig. 1B).

\section{인공와우이식 남아와 정상 청력 남아의 또래관계 인식 비교}

인공와우이식 남아와 정상 청력 남아의 비교에서, 또래관계 의 긍정적 요소인 친밀, 인정, 도움 영역의 총점은 인공와우이 식 남아가 정상 청력 남아에 비해 유의하게 낮았다 $(p=0.012)$. 하위 영역별로 살펴보았을 때 인정 영역의 평균 점수만 두 집 단 간 유의한 차이가 없었고 $(p=0.175)$, 도움 영역과 친밀 영역 의 평균 점수는 인공와우이식 남아가 정상 청력 남아에 비해 유의하게 낮았다 $(p=0.015,0.002)$ (Fig. 2A). 반면 또래관계의 부정적 요소인 갈등과 경쟁 영역의 총점은 인공와우이식 남 아와 정상 청력 남아 간 유의한 차이가 없었고 $(p=0.114)$, 각각의 하위 영역에서도 두 집단 간 유의한 차이가 없었다 $(p=0.529$, 0.081)(Fig. 2B).

\section{인공와우이식 여아와 정상 청력 여아의 또래관계 인식 비교}

인공와우이식 여아와 정상 청력 여아의 비교에서, 또래관 계의 긍정적 요소인 친밀, 인정, 도움 영역의 총점은 두 집단 간 유의한 차이가 없었다 $(p=0.754)$. 하위 영역별로 살펴보았 을 때에도 모든 영역에서 두 집단 간 유의한 차이가 나타나지 않았다 $(p=0.096,0.710,0.714)$ (Fig. $3 \mathrm{~A})$. 또래관계의 부정적 요소인 갈등과 경쟁 영역의 총점도 인공와우이식 여아와 정상
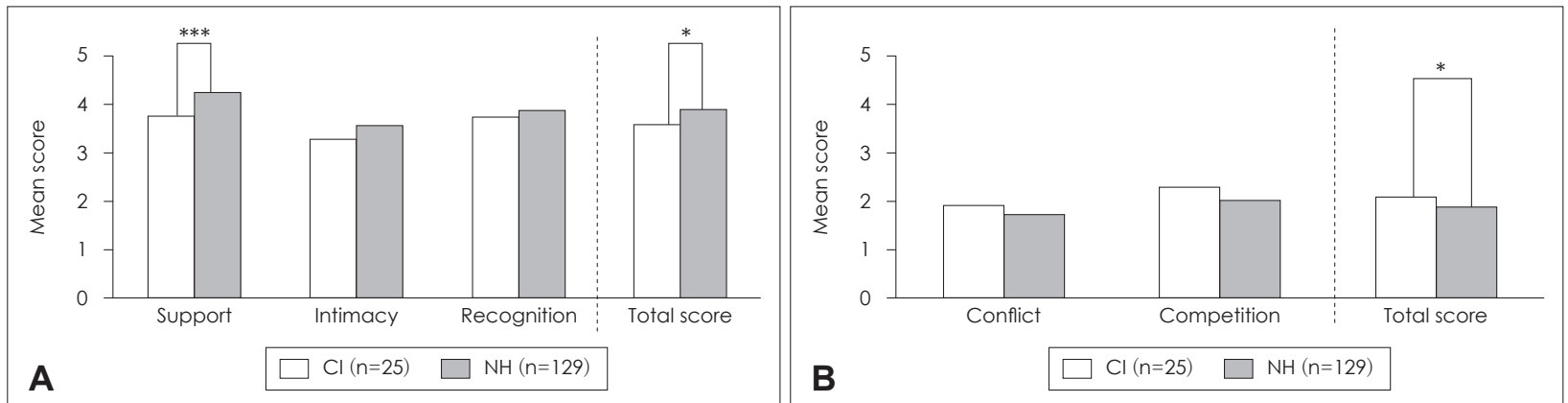

Fig. 1. Comparison of peer relations between children with $\mathrm{Cls}$ and children with $\mathrm{NH}$. Positive peer relations including support, intimacy, and recognition (A). Negative peer relations including conflict and competition (B). ${ }^{*} p<0.05,{ }^{* \star *} p<0.001$. Cl: cochlear implant, $\mathrm{NH}$ : normal hearing. 
청력 여아 간 유의한 차이를 보이지 않았고 $(p=0.262)$, 각각의 하위 영역에서도 두 집단 간 유의한 차이가 나타나지 않았다 ( $p=0.175,0.553)$ (Fig. 3B).

인공와우이식 남아의 언어능력에 따른 또래관계 인식 비교

인공와우이식 남아 11 명 중 5명은 REVT 점수가 정상치의 $-2 \mathrm{SD}$ 이하로 언어발달이 지연되어 있었고, 나머지 6 명은 -1 $\mathrm{SD}$ 이상으로 정상 언어발달을 보였다. 언어발달이 지연된 인 공와우이식 남아 $(\mathrm{n}=5)$ 는 정상 청력 남아에 비해 또래관계의 긍정적 요소인 친밀, 인정, 도움 영역의 총점이 유의하게 낮 았다 $(p=0.023)$. 하위 영역별로도 도움 영역과 친밀 영역의 평
균 점수가 유의하게 낮았으며 $(p=0.015,0.004)$ 인정 영역에서 만 두 집단 간 유의한 차이가 없었다 $(p=0.714)$ (Fig. 4A). 또래 관계의 부정적 요소인 갈등과 경쟁 영역의 총점은 언어발달 이 지연된 인공와우이식 남아 $(\mathrm{n}=5)$ 와 정상 청력 남아 간 유의 한 차이를 보이지 않았고 $(p=0.083)$, 각각의 하위 항목에서도 두 집단 간 유의한 차이가 없었다 $(p=0.464,0.105)$ (Fig. 4B).

정상 언어발달을 보인 인공와우이식 남아 $(\mathrm{n}=6)$ 는 또래관 계의 긍정적인 요소인 도움, 친밀, 인정 영역의 총점에서 정상 청력 남아와 유의한 차이를 보이지 않았고 $(p=0.139)$, 각각의 하위 영역에서도 두 집단 간 유의한 차이가 없었다 $(p=0.232$, $0.079,0.117$ )(Fig. 5A). 또래관계의 부정적 요소인 갈등과 경

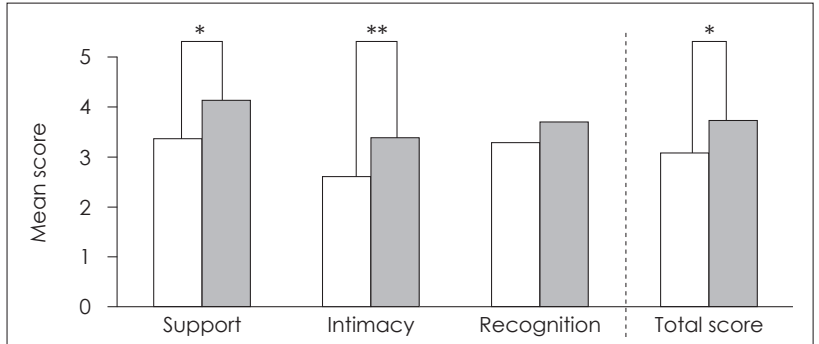

A

$\square$ Cl boys $(n=11) \quad \square$ NH boys $(n=65)$

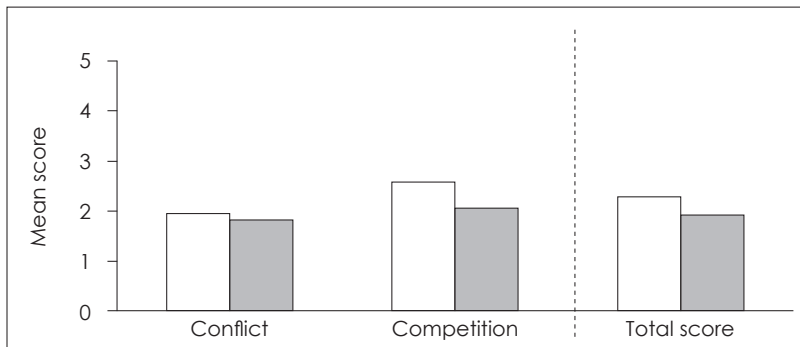

B $\square$ Cl boys $(n=11) \quad \square$ NH boys $(n=65)$

Fig. 2. Comparison of peer relations between boys with $\mathrm{Cl}$ and those with $\mathrm{NH}$. Positive peer relations including support, intimacy, and recognition (A). Negative peer relations including conflict and competition (B). ${ }^{*} p<0.05,{ }^{* *} p<0.01$. Cl: cochlear implant, $\mathrm{NH}$ : normal hearing.

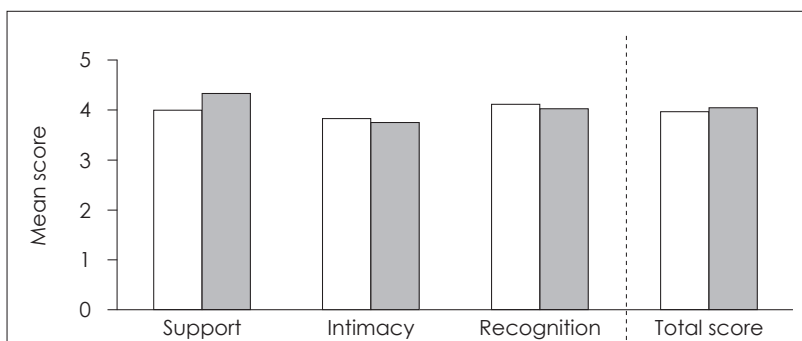

A

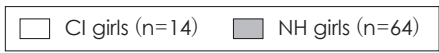

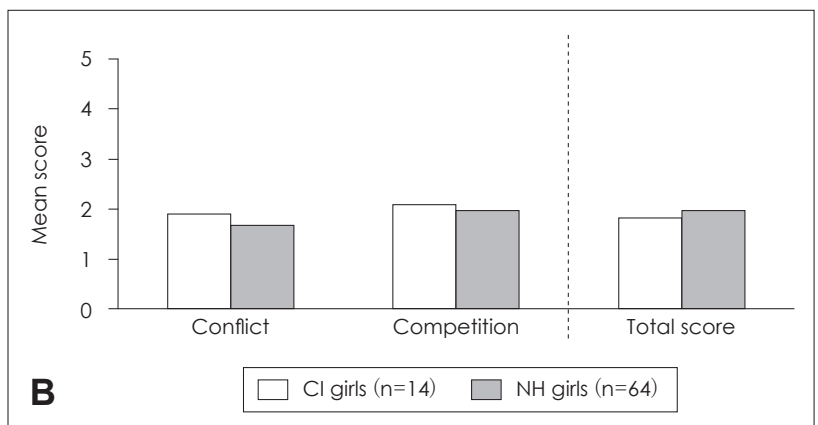

Fig. 3. Comparison of peer relations between girls with $\mathrm{Cl}$ and those with $\mathrm{NH}$. Positive peer relations including support, intimacy, and recognition (A). Negative peer relations including conflict and competition (B). $\mathrm{Cl}$ : cochlear implant, $\mathrm{NH}$ : normal hearing.

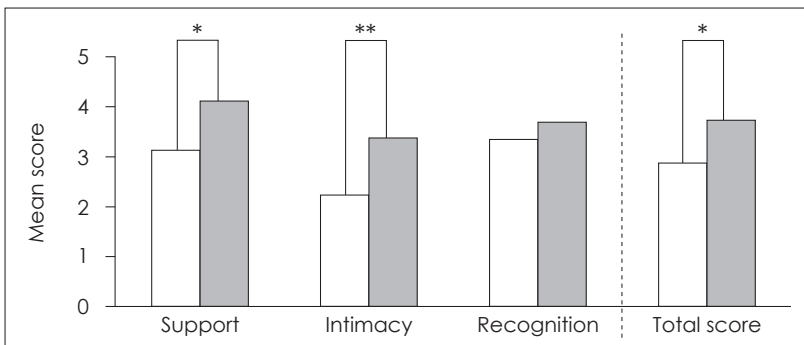

$$
\text { A } \square \text { Cl boys with poor vocabulary }(n=5) \quad \square \text { NH boys }(n=65)
$$

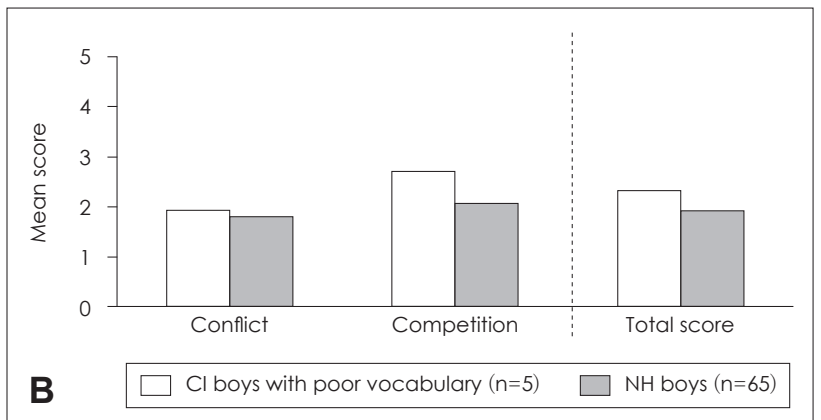

Fig. 4. Comparison of peer relations between $\mathrm{Cl}$ boys with a poor vocabulary and $\mathrm{NH}$ boys. Positive peer relations including support, intimacy, and recognition (A). Negative peer relations including conflict and competition $(\mathrm{B}) .{ }^{*} p<0.05,{ }^{* *} p<0.01$. Cl: cochlear implant, $\mathrm{NH}$ : normal hearing. 
쟁 영역의 총점에서도 정상 언어발달을 보인 인공와우이식 남 아 $(\mathrm{n}=6)$ 는 정상 청력 남아와 유의한 차이를 보이지 않았고 $(p=$ $0.521)$, 각각의 하위 영역에서도 두 집단 간 차이가 없는 것으 로 나타났다 $(p=0.827,0.330)$ (Fig. 5B).

\section{인공와우이식 여아의 언어능력에 따른 또래관계 인식 비교}

인공와우이식 여아 14 명 중 3 명은 $\mathrm{REVT}$ 점수가 정상치의

$-2 \mathrm{SD}$ 이하로 언어발달이 지연되어 있었고, 나머지 11 명은

$-1 \mathrm{SD}$ 이상으로 정상 언어발달을 보였다. 언어발달이 지연된 인공와우이식 여아 $(\mathrm{n}=3)$ 는 또래관계의 긍정적 요소인 도움, 친밀, 인정 영역의 총점에서 정상 청력 여아와 유의한 차이를
보이지 않았고 $(p=0.750)$, 각각의 하위 영역에서도 두 집단 간 유의한 차이가 나타나지 않았다 $(p=0.463,0.715,0.843)$ (Fig. $6 \mathrm{~A})$. 또래관계의 부정적 요소인 갈등과 경쟁 영역의 총점은 언어발달이 지연된 인공와우이식 여아가 정상 청력 여아에 비 해 유의하게 높았다 $(p=0.036)$. 하위 영역별로는 갈등 영역의 평균 점수는 언어발달이 지연된 인공와우이식 여아가 정상 청 력 여아에 비해 유의하게 높았으나 $(p=0.016)$ 경쟁 영역의 평균 점수는 두 집단 간 유의한 차이가 없었다 $(p=0.171)$ (Fig. 6B).

정상 언어발달을 보인 인공와우이식 여아 $(\mathrm{n}=11)$ 는 또래관 계의 긍정적 요소의 총점과 부정적 요소의 총점, 그리고 5가 지 하위 영역의 점수 모두에서 정상 청력 여아와 비교하여 유

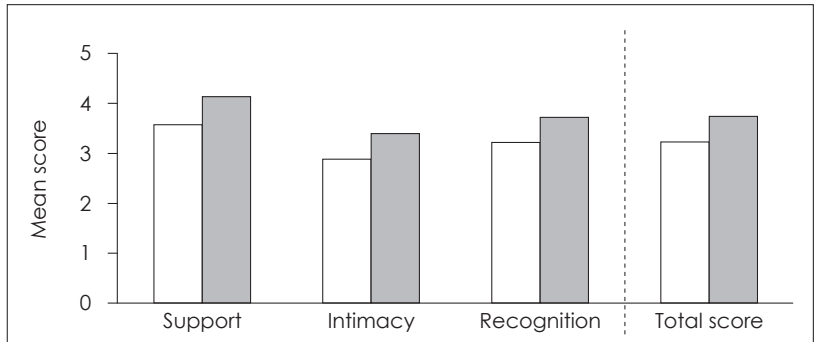

A

$\square$ Cl boys with normal vocabulary $(n=6) \square$ NH boys $(n=65)$

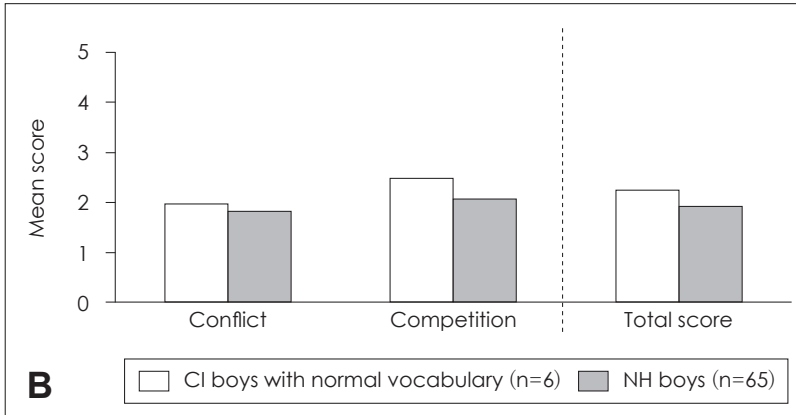

Fig. 5. Comparison of peer relations between $\mathrm{Cl}$ boys with a normal vocabulary and $\mathrm{NH}$ boys. Positive peer relations including support, intimacy, and recognition (A). Negative peer relations including conflict and competition (B). Cl: cochlear implant, $\mathrm{NH}$ : normal hearing.

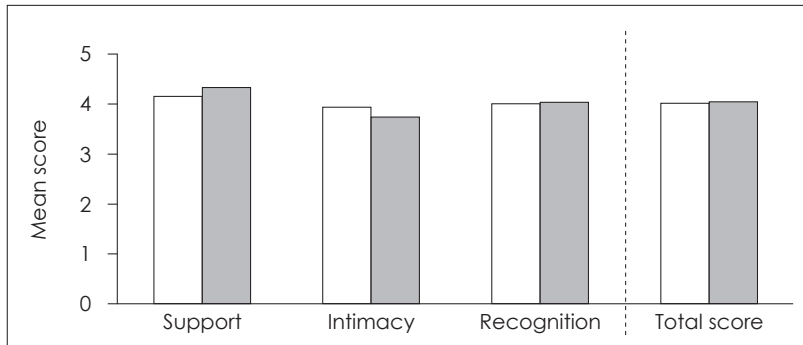

A $\square$ Cl girls with poor vocabulary $(n=3) \quad \square$ NH girls $(n=64)$

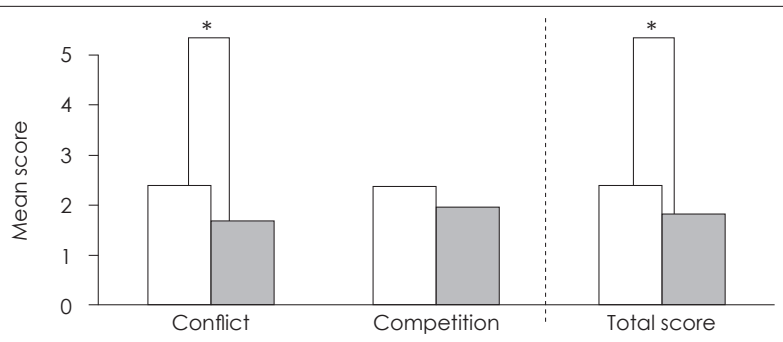

B $\square$ Cl girls with poor vocabulary $(n=3) \quad \square$ NH girls $(n=64)$

Fig. 6. Comparison of peer relations between $\mathrm{Cl}$ girls with a poor vocabulary and $\mathrm{NH}$ girls. Positive peer relations including support, intimacy, and recognition (A). Negative peer relations including conflict and competition (B). ${ }^{*} p<0.05$. Cl: cochlear implant, $\mathrm{NH}$ : normal hearing.

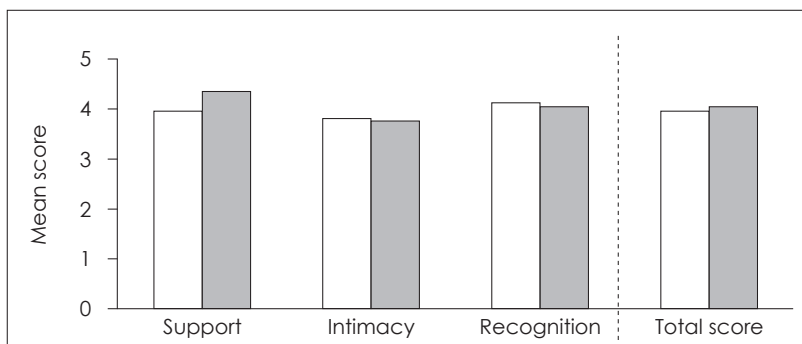

A

$\square$ Cl girls with normal vocabulary $(n=11) \square$ NH girls $(n=64)$

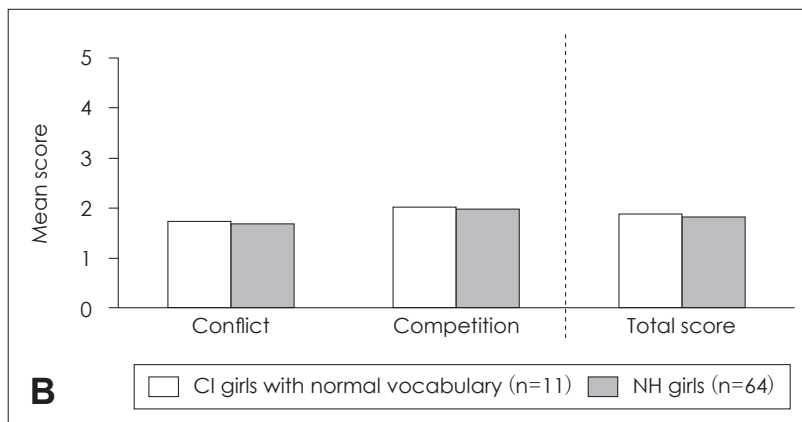

Fig. 7. Comparison of peer relations between $\mathrm{Cl}$ girls with a normal vocabulary and $\mathrm{NH}$ girls. Positive peer relations including support, intimacy, and recognition (A). Negative peer relations including conflict and competition (B). There were no significant differences between two groups in every categories. $\mathrm{Cl}$ : cochlear implant, $\mathrm{NH}$ : normal hearing. 
의한 차이를 보이지 않았다(Fig. 7).

\section{고 찰}

본 연구에서는 조기 인공와우이식과 언어재활을 통해 원 활한 구어의사소통능력을 획득한 인공와우이식 아동의 또 래관계 인식을 또래관계 척도 검사를 이용하여 살펴보았다. 또래관계 검사 척도의 다섯 가지 하위 영역 중 도움 영역을 제외한 친밀, 인정, 갈등, 경쟁의 네 가지 영역에서 인공와우 이식 아동과 정상 청력 아동 간에 유의한 차이가 없었다. 비 록 또래관계의 긍정적 요소(도움, 친밀, 인정 영역)의 합산 점 수와 부정적 요소(갈등, 경쟁 영역)의 합산 점수에서는 인공 와우이식 아동이 정상 청력 아동에 비해 부진하였으나, 인공 와우이식 아동의 평균 점수를 보면 긍정적 요소 총점의 평균 은 3.58('보통이다' 3점과 '그렇다' 4점 사이), 부정적 요소 총점 의 평균은 2.11('그렇지 않다’ 2점과 '보통이다’ 3점 사이)로 자 신의 또래관계가 비교적 원만하다고 인식하고 있는 것으로 나타났다.

국내에서는 인공와우이식 아동의 또래관계에 대한 연구 보 고가 아직 없으며, 해외에서 보고된 몇 건의 연구 결과를 살펴 보면 인공와우이식 아동의 또래관계가 정상 청력 아동에 비해 좋지 못한 것으로 보고하고 있다. ${ }^{22-25)}$ Strength and Difficulties Questionnaire(SDQ)를 사용하여 내면화 문제, 외현화 문 제, 과잉행동, 또래 문제, 친사회적 행동을 조사한 연구에서 인공와우이식 아동의 부모와 교사는 인공와우이식 아동이 정상 청력 아동에 비해 또래 문제를 더 많이 겪고 있는 것으 로 평가하였고, ${ }^{24)}$ 평균연령 14.7 세인 140 명의 인공와우이식 아동과 140 명의 정상 청력 아동을 대상으로 $\mathrm{SDQ}$ 를 시행한 연구에서는 정상 청력 아동에 비해 인공와우이식 아동의 또 래 문제가 더 큰 것으로 나타났다. ${ }^{25)}$ 이러한 보고들은 본 연 구에서 인공와우이식 아동 스스로 본인의 또래관계가 비교 적 원만하다고 인식하고 있는 것과 상반된다. 이러한 차이는 본 연구의 인공와우이식 아동의 첫 번째 인공와우이식 수술 의 평균연령이 2.0 세로 선행연구의 3.1세와 4.5 세에 비해 빨 라 더 나은 구어의사소통능력을 획득한 데에 기인한 것으로 사료된다.

본 연구에서는 인공와우이식 아동의 성별과 언어능력에 따 라 또래관계 인식에 차이를 보였다. 인공와우이식 여아의 경 우에는 또래관계 척도 검사의 다섯 가지 모든 하위 영역의 점 수에서 정상 청력 아동과 비교하여 유의한 차이를 보이지 않 았다. 반면 남아의 경우 인공와우이식 아동은 정상 청력 아동 과 비교하여 인정, 갈등, 경쟁의 세 영역에서는 유의한 차이 를 보이지 않았으나, 도움, 친밀의 두 영역 점수는 유의하게
낮았다. 언어발달 수준을 기준으로 살펴보았을 때 정상 수준 의 언어발달을 보인 인공와우이식 아동은 남녀 모두 또래관 계 인식에 있어서 정상 청력 아동과 유의한 차이를 보이지 않았고, 언어발달이 지연된 경우에는 남아에서는 도움과 친 밀의 두 영역, 여아에서는 갈등의 한 가지 영역에서 좋지 못한 또래관계 인식을 보여주었다. 이러한 결과들은 인공와우이식 남아, 특히 언어발달이 지연된 남아의 또래관계에 더 많은 관 심을 가질 필요가 있음을 시사한다고 할 수 있다. 일대일 상황 에서 효율적인 의사소통이 가능한 인공와우이식 아동이더라 도 다화자 상황이나 소음 상황에서는 듣기가 제한적이고, 이 러한 제한적인 듣기 능력으로 인해 친구들로부터 따돌림을 당하거나 오해로 인한 다툼이 발생할 수 있다. ${ }^{20,26-28)}$ 남아는 여아에 비해 다수가 모여 활동중심으로 우정을 형성하는 경 향이 있어 소음 상황과 다화자 상황에 노출되는 경우가 더 많 으므로, 정상 청력 아동과 또래관계를 형성함에 있어 여아에 비해 더 많은 어려움을 겪을 수 있다. 또한 우리나라의 정상 청력 대학생들에게 인공와우 외부기기가 잘 드러나게 착용 한 여성과 남성의 사진을 제시하고 인상을 물었을 때 인공와 우 착용 남성을 인공와우 착용 여성에 비해 더 부정적으로 평가한 선행연구 ${ }^{29}$ 의 결과에서 보듯이, 정상 청력을 가진 또 래들이 부지불식간에 인공와우이식 남아에 대한 부정적인 선입견을 가질 수 있다. 더욱이 언어발달 지연이 있는 인공와 우이식 남아의 경우에는 이러한 또래관계 문제에 미숙하게 대처할 가능성이 높고 이로 인해 긍정적인 또래관계를 형성 하는 기회가 더욱 제한될 수 있다. 본 연구에 참여한 인공와 우이식 아동 중 남아의 $45 \%$, 여아의 $21 \%$ 가 언어발달 지연을 보였는데, 이러한 인공와우이식 남아의 언어발달 지연이 이들 의 부정적 또래관계의 한 원인으로 작용하였을 것으로 사료 된다.

본 연구의 결과 중 언어능력이 정상 수준인 인공와우이식 아동은 남녀 모두 또래관계 인식의 하위 영역 중 어떠한 영역 에서도 정상 청력 아동과 차이가 없었다는 점은, 적극적인 청 각재활을 통해 인공와우이식 아동이 연령에 맞는 언어능력 을 갖추게 함으로써 또래관계에서 발생할 수 있는 문제를 예 방할 수 있음을 시사한다고 할 수 있다. 또한, 정상 청력 아동 을 대상으로 한 연구에서 또래와의 접촉 기회를 제공해 주는 등 또래와의 상호관계를 진작하는 양육행동을 보이고 풍부 한 애정 표현과 함께 권위적인 양육태도를 가진 어머니의 자 녀가 또래관계에서 더 유능하였고 ${ }^{30)}$ 아동의 사회인지발달의 정도가 또래관계에 중요한 영향을 미친다는 보고가 있으므 로 $^{31,32)}$ 올바른 양육태도 함양을 위한 부모 교육과 아동의 사 회인지발달을 증진하기 위한 교육 및 활동 프로그램 개발 등 의 노력이 인공와우이식 아동의 또래관계 개선에 도움이 될 
것으로 사료된다.

요약하면 3.5세 이전 조기 인공와우이식을 시행하고 통합 교육 환경에서 생활하는 난청 아동은 정상 청력을 가진 아 동들과 원만한 또래관계를 형성하고 있었으나 인공와우이식 아동의 또래관계 인식은 성별과 언어능력에 따라 차이를 보 였다. 인공와우이식 남아의 경우 정상 청력 남아에 비해 또래 관계를 부정적으로 인식하였고, 인공와우이식 여아는 정상 청력 여아와 비교하여 또래관계 인식에 차이를 보이지 않았 다. 언어발달이 지연된 경우 인공와우이식 여아는 정상 청력 여아에 비해 갈등을 더 크게 경험하고 인공와우이식 남아는 정상 청력 남아에 비해 도움과 친밀감이 부족하다고 인식하 고 있었지만, 언어발달이 정상 수준인 경우에는 남녀 모두 원만한 또래관계를 형성하고 있었다. 따라서 조기 인공와우 이식과 집중적인 언어재활이 정상적인 언어능력 습득뿐만 아니라 통합교육 환경에서 인공와우이식 아동의 또래관계 문 제를 예방하고 학교 적응을 높이는 방안이 될 수 있을 것이다.

\section{Acknowledgments}

This work was supported by NRF (National Research Foundation of Korea) Grant funded by the Korean Government (NRF-2016-Fostering Core Leaders of the Future Basic Science Program/Global Ph.D. Fellowship Program).

\section{REFERENCES}

1) Hartup WW. Critical issues and theoretical viewpoints. In: Rubin KH, Bukowski WM, Laursen BP, editors. Handbook of peer interactions, relationships, and groups. 1st ed. New York: The Guilford Press; 2009. p.3-19.

2) Hartup WW. Friendships and their developmental significance. In: McGurk H, editor. Childhood social development: contemporary perspectives. 1st ed. London: Psychology Press;1992. p.175-206.

3) Eckerman CO, Davis CC, Didow SM. Toddlers' emerging ways of achieving social coordinations with a peer. Child Dev 1989;60(2): 440-53.

4) Parker JG, Asher SR. Friendship and friendship quality in middle childhood: links with peer group acceptance and feelings of loneliness and social dissatisfaction. Dev Psychol 1993;29(4):611-21.

5) Rubin K, Bukowski W, Parker J. Peer interactions, relationships, and groups. In: Damon W, Lerner RM, editors. Handbook of child psychology: vol. 3. social, emotional, and personality development. 6th ed. New York: Wiley;2006. p.571-645.

6) Bukowski WM, Hoza B. Popularity and friendship: issues in theory, measurement, and outcome. In: Berndt TJ, Ladd GW, editors. Peer relationships in child development. 1st ed. New York: Wiley;1989. p.71-4.

7) Furman W, Buhrmester D. Children's perceptions of the personal relationships in their social networks. Dev Psychol 1985;21(6):1016-22.

8) Ellis S, Rogoff B, Cromer CC. Age segregation in children's social interactions. Dev Psychol 1981;17(4):399-407.

9) Harter S. The self. In: Damon W, Lerner RM, editors. Handbook of child psychology: vol. 3. social, emotional, and personality development. 6th ed. New York: Wiley;2006. p.505-70.

10) Coolahan K, Fantuzzo J, Mendez J, McDermott P. Preschool peer interactions and readiness to learn: relationships between classroom peer play and learning behaviors and conduct. J Educ Psychol 2000; 92(3):458-65.
11) Yang WK. The relations between peer acceptance and peer victimization and self-esteem in adolescents [dissertation]. Seoul: Ewha Womans Univ.;1999.

12) Barnow S, Lucht M, Freyberger HJ. Correlates of aggressive and delinquent conduct problems in adolescence. Aggress Behav 2005; 31(1):24-39.

13) Bagwell CL, Newcomb AF, Bukowski WM. Preadolescent friendship and peer rejection as predictors of adult adjustment. Child Dev 1998; 69(1):140-53.

14) Archbold S, Mayer C. Deaf education: the impact of cochlear implantation? Deafness Educ Int 2012;14(1):2-15.

15) Colletti L. Long-term follow-up of infants (4-11 months) fitted with cochlear implants. Acta Otolaryngol 2009;129(4):361-6.

16) Geers AE, Brenner CA, Tobey EA. Long-term outcomes of cochlear implantation in early childhood: sample characteristics and data collection methods. Ear Hear 2011;32(1 Suppl):2S-12.

17) Geers AE, Davidson LS, Uchanski RM, Nicholas JG. Interdependence of linguistic and indexical speech perception skills in school-age children with early cochlear implantation. Ear Hear 2013;34(5): 562-74.

18) Bukowski WM, Kramer TL. Judgments of the features of friendship among early adolescent boys and girls. J Early Adolesc 1986;6(4):331-8.

19) Moon EJ, Sim HO. Relationships between children's friendship quality, self-perception and school adjustment. Korean J Child Stud 2001;22(4):99-113.

20) Bat-Chava Y, Deignan E. Peer relationships of children with cochlear implants. J Deaf Stud Deaf Educ 2001;6(3):186-99.

21) Jung MK. A Study on the relationship between the children's perception of the parental rearing attitudes and the peer relationships [dissertation]. Seoul: Seoul Women's Univ.;2002.

22) Fitzpatrick EM, Olds J. Practitioners' perspectives on the functioning of school-age children with cochlear implants. Cochlear Implants Int 2015;16(1):9-23.

23) Stevenson J, Kreppner J, Pimperton H, Worsfold S, Kennedy C. Emotional and behavioural difficulties in children and adolescents with hearing impairment: a systematic review and meta-analysis. Eur Child Adolesc Psychiatry 2015;24(5):477-96.

24) Niclasen J, Dammeyer J. Psychometric properties of the strengths and difficulties questionnaire and mental health problems among children with hearing loss. J Deaf Stud Deaf Educ 2016;21(2):129-40.

25) Huber M, Burger T, Illg A, Kunze S, Giourgas A, Braun L, et al. Mental health problems in adolescents with cochlear implants: peer problems persist after controlling for additional handicaps. Front Psychol 2015;6:953.

26) Punch R, Hyde M. Social participation of children and adolescents with cochlear implants: a qualitative analysis of parent, teacher, and child interviews. J Deaf Stud Deaf Educ 2011;16(4):474-93.

27) Punch R, Hyde MB. Communication, psychosocial, and educational outcomes of children with cochlear implants and challenges remaining for professionals and parents. Int J Otolaryngol 2011;2011:573280.

28) Rich S, Levinger M, Werner S, Adelman C. Being an adolescent with a cochlear implant in the world of hearing people: coping in school, in society and with self identity. Int J Pediatr Otorhinolaryngol 2013; 77(8):1337-44.

29) Heo MJ, Kim LS, Ahn SW, Boo SH. Perception and attitude of university students for hearing aid and cochlear implant: hearing aid effect and cochlear implant effect. Journal of Special Education: Theory and Practive 2008;9(3):61-81.

30) Park JH, Rhee UH. Children's peer competence: relationships to maternal parenting goals, parenting behaviors, and management strategies. Korean J Child Stud 2001;22(4):1-15.

31) Oden $S$, Asher SR. Coaching children in social skills for friendship making. Child Dev 1977;48(2):495-506.

32) Wellman HM. Friends, friendlessness, and social cognition. Br J Dev Psychol 2015;33(1):24-6. 